\title{
Synchronous papillary endometrial and ovarian cancer in a 64-year-old woman
}

\author{
Ganesh B. Bharaswadkar ${ }^{1 *}$, Nalan Babacan ${ }^{2}$
}

\author{
${ }^{1}$ Department of Obstetrics and Gynecology, BDF Hospital, Riffa, Bahrain \\ ${ }^{2}$ Department of Medical Oncology, Bahrain Oncology Center, Bahrain
}

Received: 23 October 2021

Revised: 13 December 2021

Accepted: 14 December 2021

\section{*Correspondence:}

Dr. Ganesh B. Bharaswadkar,

E-mail: ganeshbbbb@gmail.com

Copyright: (c) the author(s), publisher and licensee Medip Academy. This is an open-access article distributed under the terms of the Creative Commons Attribution Non-Commercial License, which permits unrestricted non-commercial use, distribution, and reproduction in any medium, provided the original work is properly cited.

\begin{abstract}
Obesity, nulliparity, and comparatively younger age may attribute a "hormonal field effect" which leads to the development of synchronous endometrioid cancers. The morphological unit consisting of the uterus, fallopian tubes, and ovary as part of the Mullerian system may explain the synchronous appearance of these malignancies. Synchronous endometrial and ovarian cancer (SEOC) is defined as the simultaneous presence of these dual cancers at the time of diagnosis as opposed to metachronous cancer where these two cancers are diagnosed at different chronologic time points. Synchronous malignancies in the female genital tract are very rare entities. Synchronous endometrial and ovarian tumors must be differentiated from either primary endometrium or ovarian tumors with metastasis. The landmark criteria for diagnosing such cases have been laid down by Ulbright and Roth.
\end{abstract}

Keywords: Synchronous papillary endometrial, Ovarian cancer, Mullerian system

\section{INTRODUCTION}

Synchronous endometrial and ovarian cancer (SEOC) is defined as the simultaneous presence of these two cancers at the time of diagnosis as opposed to metachronous cancer where these two cancers are diagnosed at different chronologic time points. ${ }^{1}$ Synchronous malignancies in the female genital tract are very rare entities (0.5-1.7\%). Among them, synchronous endometrial and ovarian tumors are the most common types of malignancy, with a frequency of $5 \%$ among endometrial and $10 \%$ among ovarian primary tumors., ${ }^{2,3}$

Synchronous endometrial and ovarian tumors are rare variants of gynecological cancers, and they must be differentiated from either primary endometrium or ovarian tumors with metastasis. The landmark criteria have been laid down by Ulbright and Roth, and later refined substantially by Scully et al. ${ }^{4,6}$
Obesity has resulted in changing trends of endometrial disease, resulting in a gradual increase in the incidence of the disease in the past few decades. ${ }^{7,8}$ Menopausal hormonal therapy as well as the use of oral contraceptives have caused a steady fall in the incidence of ovarian cancer. Many theories have been proposed about these relative proportions of synchronous tumors, which include changing demographic trends and the introduction of diagnostic criteria in 1980, which was adopted by many centers in later years. ${ }^{9-11}$

Factors such as obesity, nulliparity, and comparatively younger age may attribute a "hormonal field effect" to the development of synchronous endometrioid cancers. The morphological unit consisting of the uterus, fallopian tubes, and ovary as part of the Mullerian system may explain the synchronous appearance of these malignancies. ${ }^{12}$ Niskakoski et al have suggested a shared origin of synchronous endometrial and ovarian carcinoma 
in Lynch syndrome (LS), indicating converging pathways of tumorigenesis. L1 cell adhesion molecule (L1CAM) overexpression was significantly common (43\%) among synchronous patients. ${ }^{13}$ The mentioned case reported here was diagnosed incidentally after the patient underwent surgical staging for endometrial cancer.

\section{CASE REPORT}

We present the case of 64-year-old female para 6 came with complaints of postmenopausal per vaginal bleeding for 2 weeks. History of onset of menopause 10 years back. She was a known case of diabetes mellitus and hypertension on treatment. On clinical examination, per abdominal no mass was felt and cervix looked normal on per speculum examination. On transvaginal scan, uterus measured $6.5 \mathrm{~cm}$, ovaries were small, endometrial thickness 8-9 mm. Computed tomography (CT) pelvis revealed intraluminal endometrial soft tissue lesion infiltrating anterior mucosa and few inner millimeters of myometrium suggestive of stage I endometrial carcinoma. Hence endometrial sampling was done by thorough dilatation and curettage which was suggestive of endometrial adenocarcinoma, moderate grade. Total abdominal hysterectomy with bilateral salpingooophorectomy with omental and peritoneal fluid sampling was done. Intra-operative findings were small uterus with elongated cervix. Right ovary having abnormal small cauliflower like growth. There was no evidence of gross peritoneal and omental deposits with mild amount of free peritoneal fluid. Histo-pathology of the specimen revealed polypoidal endometrial carcinoma (papillary cribriform subtype) histologic grade FIGO grade 2 with less than $50 \%$ myometrial invasion and right ovarian papillary serous adenocarcinoma, low grade stage $1 \mathrm{C}$. Peritoneal fluid was positive for malignancy with no involvement of omentum. Case was discussed in multidisciplinary tumor board meeting and was advised adjuvant chemotherapy. Her post-operative blood CA125 level was: $10 \mathrm{u} / \mathrm{ml}(0-35$ $\mathrm{u} / \mathrm{ml}$ ). She completed 4 cycles of adjuvant chemotherapy ( 2 cycles paclitaxel-carboplatin and 2 cycles docetaxelcarboplatin, taxane changed due to grade 3 sub-acute body pain side effect) on 10/3/2021. Mutation analysis showed there is no BRCA 1, 2 mutation, just NF1 (variant of unknown significance) detected. Follow up magnetic resonance imaging (MRI) pelvis (01/03/2021) has proved there is no recurrent or residual mass lesion. Currently she is under regularly follow up.

Table 1: Factors associated with synchronous endometrial and ovarian cancer in comparison to other types. ${ }^{15}$

\begin{tabular}{|c|c|c|c|}
\hline No. & $\begin{array}{l}\text { Primary endometrial cancer } \\
\text { with ovarian metastasis }\end{array}$ & $\begin{array}{l}\text { Primary ovarian cancer with } \\
\text { endometrial metastasis }\end{array}$ & $\begin{array}{l}\text { Independent primary endometrial } \\
\text { and ovarian tumours }\end{array}$ \\
\hline 1 & Histologic similarity of tumours & Histologic similarity of tumours & Histologic dis-similarity of tumours \\
\hline 2 & $\begin{array}{l}\text { Large endometrial and small } \\
\text { ovarian tumour }\end{array}$ & $\begin{array}{l}\text { Large ovarian and small } \\
\text { endometrial tumour }\end{array}$ & \\
\hline 3 & $\begin{array}{l}\text { Atypical endometrial } \\
\text { hyperplasia additionally present }\end{array}$ & $\begin{array}{l}\text { No atypical endometrial } \\
\text { hyperplasia }\end{array}$ & Atypical endometrial hyperplasia \\
\hline 4 & Deep myometrial invasion & Location in ovarian parenchyma & $\begin{array}{l}\text { No or only superficial invasion of } \\
\text { endometrial tumour }\end{array}$ \\
\hline
\end{tabular}

\section{DISCUSSION}

Synchronous endometrial and ovarian tumors are rare variants of gynecological cancers, and they must be differentiated from either primary endometrium or ovarian tumors with metastasis. The landmark criteria have been laid down by Ulbright and Roth, and later refined substantially by Scully et al.,

Menopausal hormonal therapy as well as the use of oral contraceptives have caused a steady fall in the incidence of ovarian cancer. In the past, pathologic criteria by Ulbright and Roth were used in order to distinguish synchronous primary tumors from metastasis. ${ }^{4}$

SEOCs are characterized by histological dissimilarity of the tumors, no or only superficial myometrial invasion of endometrial cancer, no vascular space invasion of endometrial and ovarian tumor, absence of other evidence of spread, ovarian unilateral tumor, ovarian tumor in the parenchyma and without involvement of the surface of the ovary, dissimilarity of molecular genetic or karyotypic abnormalities in the tumors, and different ploidy of DNA of the tumors. ${ }^{5}$ Young age, obesity, pre-menopausal status, and nulliparity were the distinct features among this rare entity. Three cases in perimenopausal and postmenopausal age group has been reported by gynecological oncology unit at "Attikon" University Hospital, National University of Athens, Greece to be synchronous endometrioid endometrial and ovarian cancer. ${ }^{14}$

\section{CONCLUSION}

Synchronous endometrial and ovarian tumors are rare variants of gynecological cancers, and they must be differentiated from either primary endometrium or ovarian tumors with metastasis. The landmark criteria for diagnosing such cases have been laid down by Ulbright and Roth.

\section{Funding: No funding sources \\ Conflict of interest: None declared \\ Ethical approval: Not required}




\section{REFERENCES}

1. Matsuo K, Machida H, Blake EA, Holman LL, Rimel BJ, Roman LD, Wright JD. Trends and outcomes of women with synchronous endometrial and ovarian cancer. Oncotarget. 2018;9(47):28757-71.

2. Kelemen LE, Rambau PF, Koziak JM, Steed H, Köbel M. Synchronous endometrial and ovarian carcinomas: predictors of risk and associations with survival and tumor expression profiles. Cancer Causes Control. 2017;28:447-57.

3. Zaino R, Whitney C, Brady MF, DeGeest K, Burger RA, Buller RE. Simultaneously detected endometrial and ovarian carcinomas-a prospective clinicopathologic study of 74 cases: a gynecologic oncology group study. Gynecol Oncol. 2001;83:35562.

4. Ulbright TM, Roth LM. Metastatic and independent cancers of the endometrium and ovary: a clinicopathologic study of 34 cases. Hum Pathol. 1985;16:28-34.

5. Scully R, Young R, Clement P. Tumors of the Ovary, Maldeveloped Gonads, Fallopian Tube and Broad Ligament: Atlas of Tumor Pathology. Bethesda: Armed Forces Institute of Pathology. 1998.

6. Scully RE, Young RH, Clement PB. Tumors of the Ovary, Maldeveloped Gonads, Fallopian Tube, and Broad Ligament: Atlas of Tumor Pathology (Afip Atlas of Tumor Pathology No. 23). Amer Registry of Pathology, Silver Spring, MD. 1998.

7. Centers for Disease Control and Prevention: National Center for Health Statistics. 2015. Available at: https://www.cdc.gov/nchs/\%20data/hestat/overweigh t/overweight_adult.htm. Accessed on 12 July 2020.

8. National Cancer Institute: Surveillance, Epidemiology, and End Results Program. Cancer stat facts - endometrial cancer. 2017. Available at: https://seer.cancer.gov/statfacts/html/corp.html. Accessed on 12 July 2020:

9. National Cancer Institute: Surveillance, Epidemiology, and End Results Program. Cancer stat facts: ovarian cancer. 2017. Available at: https://seer.cancer.gov/statfacts/html/ovary.html. Accessed on 12 July 2020.

10. Morris CR, Rodriguez AO, Epstein J, Cress RD. Declining trends of epithelial ovarian cancer in California. Gynecol Oncol. 2008;108:207-13.

11. Yang HP, Anderson WF, Rosenberg PS. Ovarian cancer incidence trends in relation to changing patterns of menopausal hormone therapy use in the United States. J Clin Oncol. 2013;31:2146-51.

12. Eifel P, Hendrickson M, Ross J, Ballon S, Martinez A, Kempson R. Simultaneous presentation of carcinoma involving the ovary and the uterine corpus. Cancer. 1982;50:163-70.

13. Niskakoski A, Pasanen A, Porkka N. Converging endometrial and ovarian tumorigenesis in Lynch syndrome: shared origin of synchronous carcinomas. Gynecol Oncol. 2018;150:92-8.

14. Makris G, Manousopoulou G, Battista M, Salloum I, Chrelias G, Chrelias C: Synchronous Endometrial and Ovarian Carcinoma: A Case Series. Case Rep Oncol. 2017;10:732-6.

15. de la Noval BD. Factors associated with Synchronous Endometrial and Ovarian Cancer, Review of a Case. Crit Care Obst Gyne. 2016;2:4.

Cite this article as: Bharaswadkar GB, Babacan N. Synchronous papillary endometrial and ovarian cancer in a 64-year-old woman. Int J Reprod Contracept Obstet Gynecol 2022;11:252-4. 